\title{
Daya Dukung Lahan Pertanian, Permukiman, dan Kawasan Lindung di DAS Sembung, Kabupaten Sleman, DIY
}

\author{
${ }^{1}$ Arum Sari Widiastuti, ${ }^{1}$ Deka Ayu Maretya, ${ }^{1}$ Gina Aprila Wangge, ${ }^{1}$ Amalya Suci, ${ }^{1}$ Afid Nurkholis, ${ }^{1}$ Yuli \\ Widyaningsih, ${ }^{1}$ Ayu Dyah Rahma, ${ }^{1}$ Ardian Abdillah \\ ${ }^{1}$ Departemen Geografi Lingkungan, Fakultas Geografi, Universitas Gadjah Mada \\ email author: $\underline{\text { arumsariwidiastuti@gmail.com }}$
}

\begin{abstract}
Abstrak
Pembangunan wilayah di DAS Sembung yang semakin meningkat menjadikan analisis daya dukung terhadap lahan permukiman, pertanian, dan kawasan lindung perlu dilakukan. Analisis ketiga daya dukung tersebut dilakukan secara spasial berdasarkan bentuklahan yang terdiri dari lereng kaki, dataran kaki, dan teras sungai. Hasil penelitian menunjukkan bahwa daya dukung terhadap permukiman menunjukkan bahwa pada lereng kaki dan dataran kaki memiliki daya dukung yang tinggi sedangkan pada bentuklahan teras sungai memiliki daya dukung permukiman yang rendah. Hal ini dipengaruhi oleh faktor luas lahan layak permukiman dan jumlah penduduk pada masing-masing bentuklahan. Hasil perhitungan daya dukung pertanian menunjukkan bahwa lereng kaki memiliki daya dukung yang tergolong tinggi sedangkan pada dataran kaki dan teras sungai memiliki daya dukung yang rendah, hal ini disebabkan karena tekstur tanah di lereng kaki adalah geluh berpasir yang cocok untuk pertanian sedangkan tektur tanah pada dataran kaki dan teras sungai dominan pasir. Hasil perhitungan daya dukung lindung menunjukkan bahwa pada bentuklahan lereng kaki dan dataran kaki memiliki daya dukung yang tergolong rusak sedangkan pada teras sungai tergolong sedang. Hal ini sangat dipengaruhi oleh kondisi alami yang ada pada lereng kaki dan dataran kaki telah banyak berubah akibat aktivitas manusia.
\end{abstract}

kata kunci: daya dukung lahan pertanian, daya dukung untuk permukiman, daya dukung kawasan lindung, daya dukung lingkungan, DAS Sembung, Kabupaten Sleman

\section{$\underline{\text { Sitasi model APA }}$}

Widiastuti, A. S., Maretya, D. A., Wangge, G. A., Suci, A., Nurkholis, A., Widyaningsih, Y., Rahma, A. D., Abdillah, A. 2016. Daya Dukung Lahan Pertanian, Permukiman, dan Kawasan Lindung di DAS Sembung, Kabupaten Sleman, DIY. http://doi.org/10.17605/OSF.IO/VBW4P 


\section{PENDAHULUAN}

Barrow (1991) mendefinisikan degradasi lahan sebagai hilangnya atau berkurangnya kegunaan atau potensi kegunaan lahan untuk mendukung kehidupan. Kehilangan atau perubahan kenampakkan tersebut menyebabkan fungsinya tidak dapat diganti oleh yang lain. Proses geomorfologis yang berlangsung akan berdampak baik langsung maupun tidak langsung terhadap kondisi fisikal permukaan bumi. Proses geomorfologis mengakibatkan turunnya kualitas dan daya dukung lahan yang selanjutnya akan menyebabkan degdarasi lahan. Sementara itu degradasi lahan yang disebabkan oleh aktivitas manusia terjadi akibat akibat pemanfaatan lingkungan oleh manusia yang tidak memerhatikan keseimbangan lingkungan.

Daya dukung lahan merupakan kemampuan suatu lingkungan untuk mendukung kehidupan. Untuk daya dukung lahan agraris (pertanian) pada dasarnya bergantung pada persentasi lahan yang dapat dipakai untuk pertanian dan besarnya hasil pertanian persatuan luas dan waktu. Makin besar persentase lahan yang dapat digunakan sebagai lahan pertanian makin besar pula daya dukung lahan daerah tersebut (Soemarwoto, 1983). Untuk menunjang kehidupannya, manusia tidak hanya membutuhkan lahan yang digunakan sebagai lahan pertanian tetapi juga membutuhkan lahan untuk dijadikan permukiman dan aktivitas sosial ekonomi yang lain. Semakin tinggi jumlah penduduk akan menyebabkan kebutuhan lahan untuk permukiman juga semakin tinggi, hal ini akan menyebabkan terjadinya penurunan daya dukung lahan. Menurut Soerjani (1987), pengertian daya dukung lingkungan adalah batas teratas dari pertumbuhan suatu populasi saat jumlah populasi tidak dapat didukung lagi oleh sarana, sumber daya dan lingkungan yang ada.

\section{WILAYAH KAJIAN}

DAS Sembung merupakan bagian dari DAS Opak. DAS Sembung dibagi menjadi tiga zonasi yaitu hulu, tengah, dan hilir. Penutup lahan yang dominan di DAS Sembung yaitu sebagai pertanian, perkebunan, dan permukiman. Klasifikasi lereng di DAS Sembung berupa lereng yag datar dan landai. Formasi batuan yang terdapat pada DAS Sembung berupa Qmi/ Qvu3 yaitu Endapan Volkanik Merapi Muda yang terdiri dari tuff, abu, breksi, aglomerat, dan leleran lava tak terpisahkan. Formasi ini berhulu pada Gunungapi Merapi dan menyusun sebagian besar lereng Gunung Merapi. Formasi berumur kuarter dan masih terus mengalami proses erupsi. Material yang tersusun merupakan hasil dari akumulasi erupsi Gunung Merapi. DAS Sembung memiliki tiga bentuklahan, yaitu lereng kaki volkanik, dataran kaki volkanik, dan teras sungai (Gambar 2.1). 


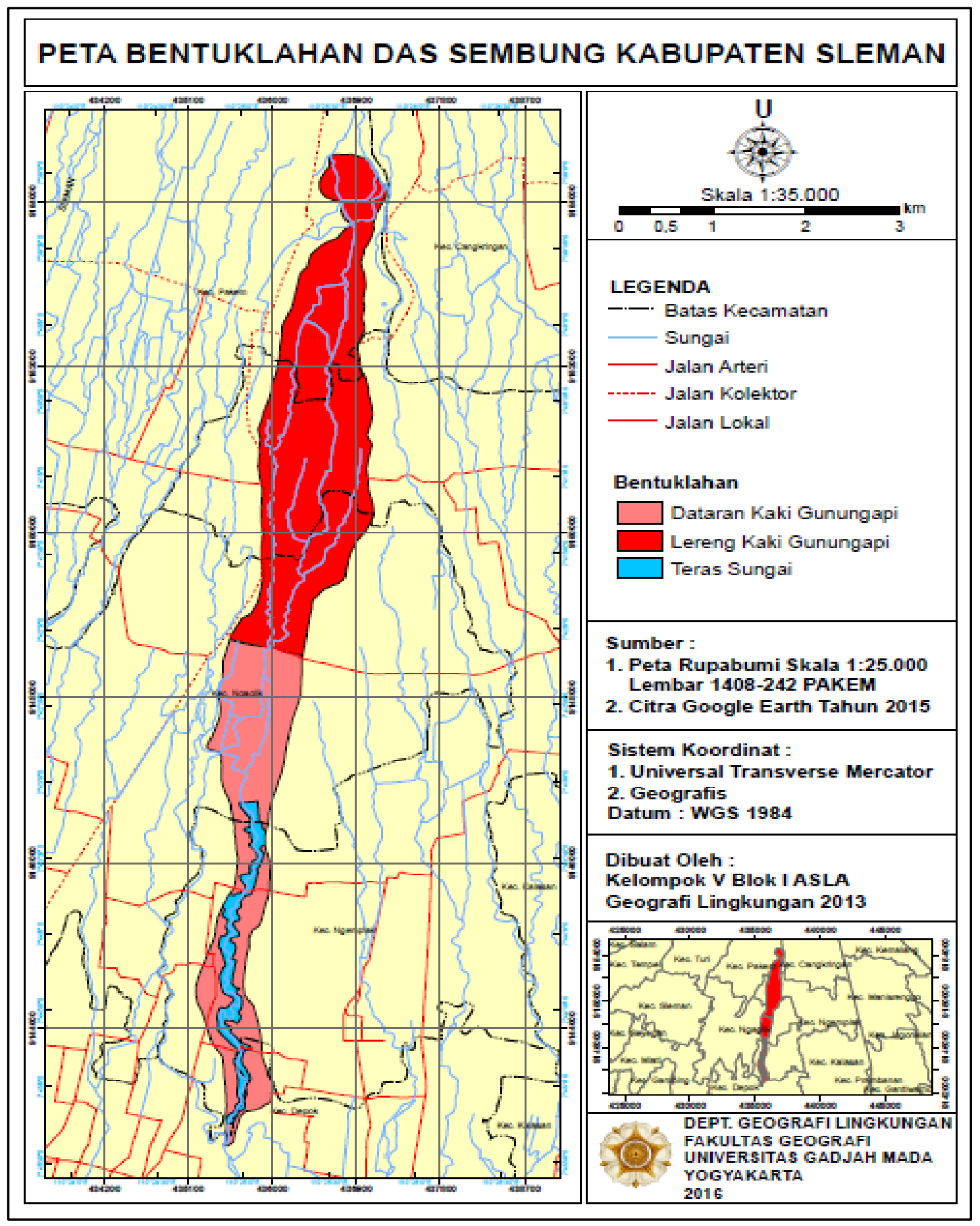

Gambar 2.1. Peta Bentuklahan DAS Sembung

\section{METODE PENELITIAN}

\subsection{Daya Dukung Lahan Permukiman}

Pertumbuhan penduduk yang semakin meningkat menyebabkan kebutuhan lahan untuk permukiman semakin meningkat. Oleh karena itu, evaluasi terhadap daya dukung wilayah untuk 
penggunaan lahan permukiman perlu dilakukan. Data yang dibutuhkan adalah data luas lahan dan data jumlah penduduk (Gambar 3.1).

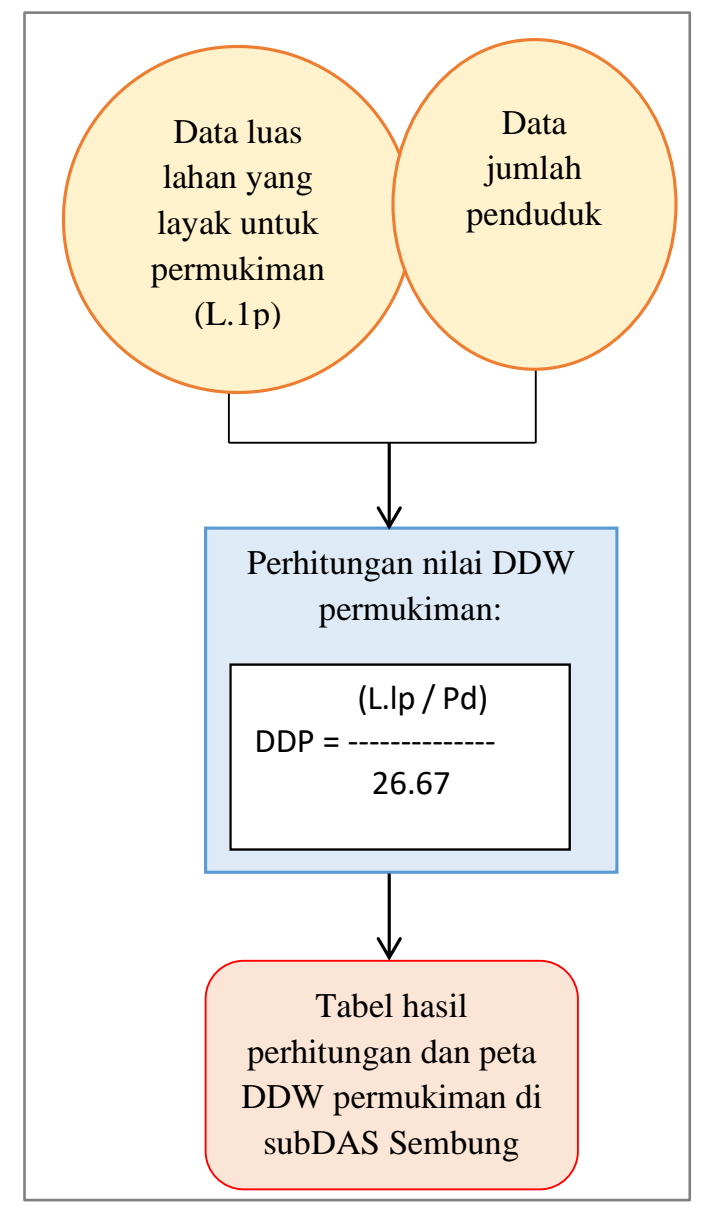

Gamabar 3.1. Perhitungan Daya Dukung Wilayah Permukiman

\subsection{Daya Dukung Lindung}

Perhitungan daya dukung lindung menunjukkan lahan yang masih alami dan belum mengalami pengolahan secara intensif sehingga masih memiliki fungsi sebagai kawasan lindung. Data yang digunakan adalah data luas wilayah dan luas masing-masing penggunaan lahan (Gambar 3.2).

\subsection{Daya Dukung Lahan Pertanian}

Pada sektor pertanian, kemampuan daya dukung (Carrying Capacity Ratio) merupakan perbandingan antara lahan yang tersedia dan jumlah petani. Data yang digunakan adalah luas lahan rata-rata yang dibutuhkan per kepala keluarga, potensi lahan yang tersedia dan penggunaannya untuk kegiatan pertanian. Analisis ini dijelaskan pada Gambar 3.3. 


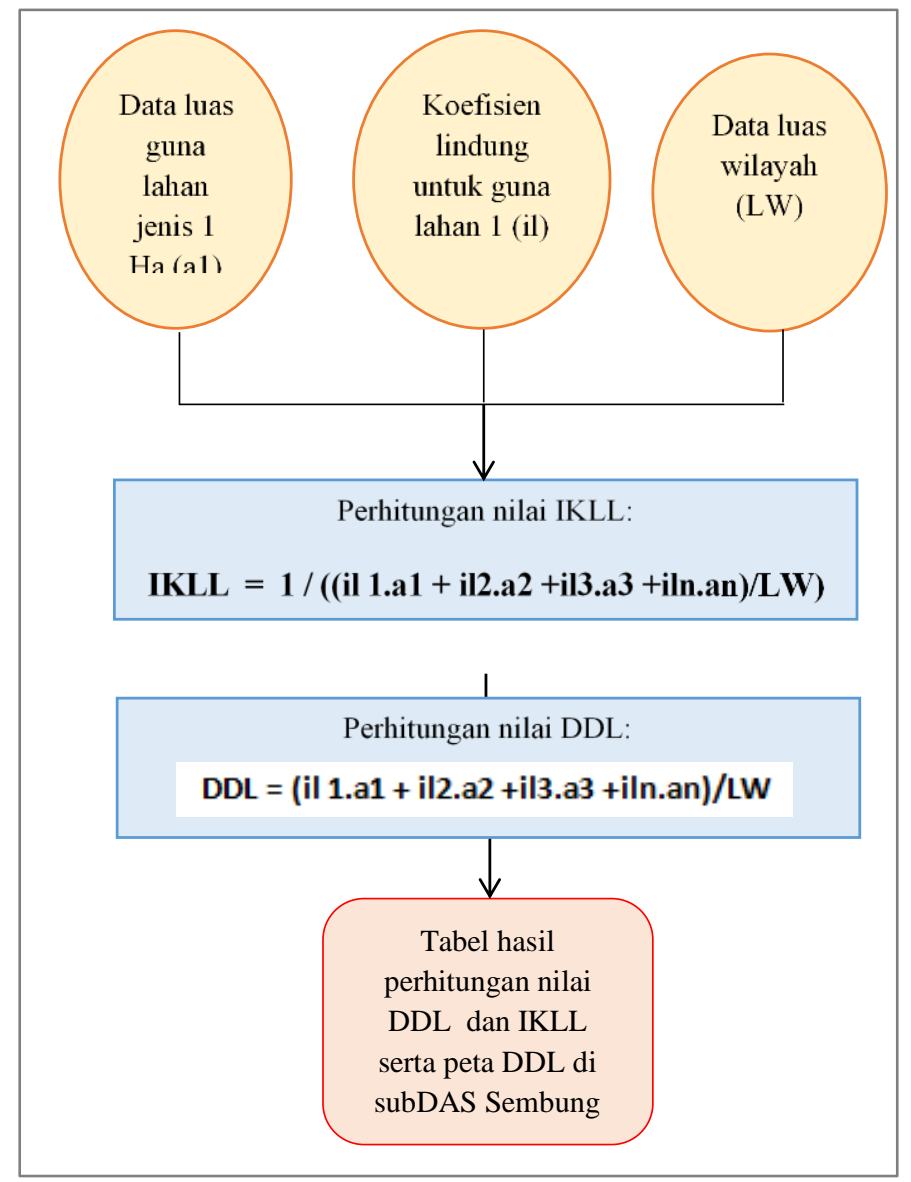

Gambar 3.2. Perhitungan Daya Dukung Kawasan Lindung

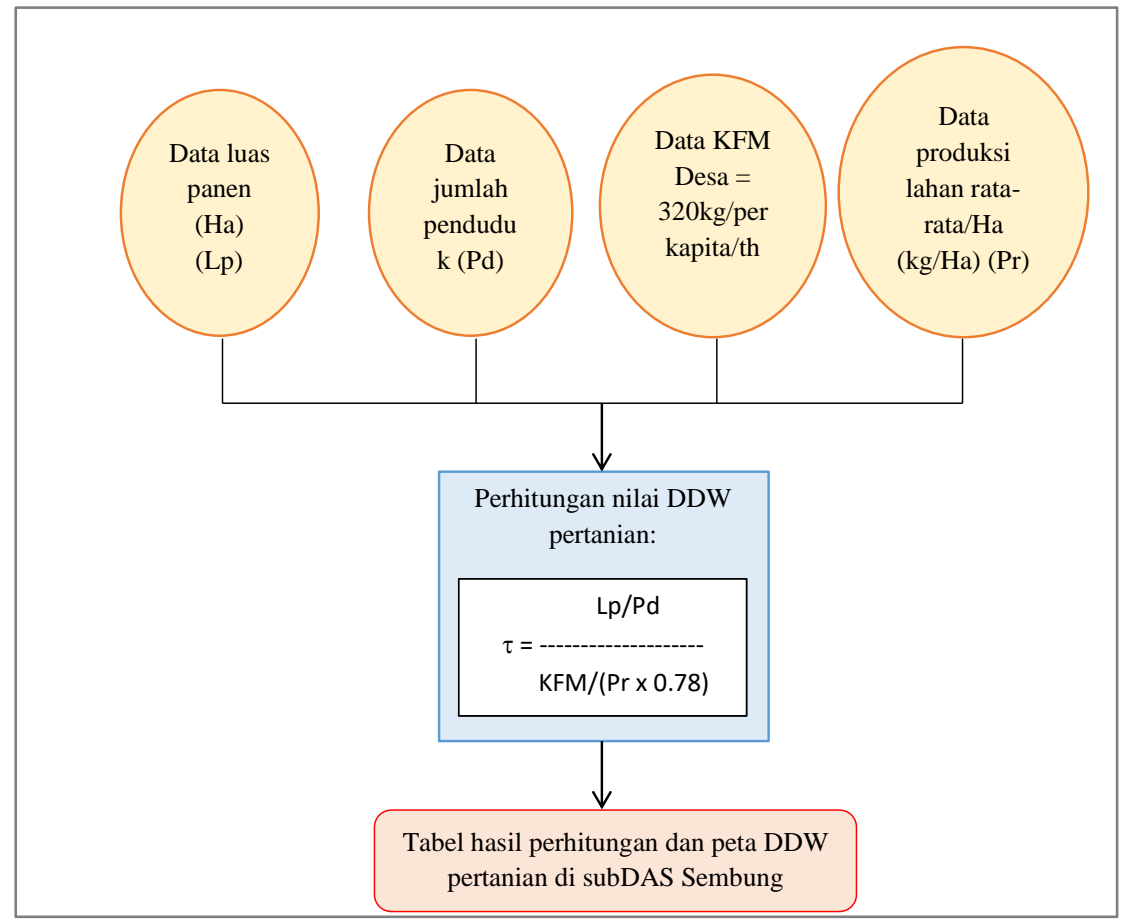

Gambar 3.3. Perhitungan Daya Dukung Wilayah Pertanian 


\section{HASIL DAN PEMBAHASAN}

\section{A. Daya Dukung Wilayah terhadap Permukiman}

Daya Dukung Wilayah terhadap Permukiman digunakan untuk menghitung luasan lahan yang dapat digunakan untuk permukiman berdasarkan data jumlah penduduk dan data luas lahan yang layak untuk permukiman. Daya Dukung Wilayah terhadap Permukiman pada DAS Sembung dihitung berdasarkan satuan bentuklahan yang ada meliputi bentuklahan lereng kaki dan dataran kaki gunungapi.

Hasil perhitungan DDW (Daya Dukung Wilayah) untuk permukiman pada bentuklahan lereng kaki adalah sebesar 6,1 yang menunjukkan bahwa bentuklahan ini dapat mendukung penggunaan lahan permukiman dengan klasifikasi tinggi (Tabel 4.1 dan Gambar 4.1). Hasil perhitungan DDP (Daya Dukung Permukiman) sangat tergantung pada luas lahan layak untuk permukiman (L.Lp) yang diperoleh melalui pendekatan kemampuan lahan. Lahan yang memiliki kemampuan lahan I-IV memiliki luas lahan yang layak digunakan sebagai lahan pertanian sebesar $30 \%$ dari total luas lahan yang ada. Lahan yang berada di lereng kaki ini memiliki kemampuan lahan kelas I-II sehingga data L.Lp diperoleh melalui 30\% luas lahan yang ada pada masingmasing bentuklahan yang dibedakan berdasarkan luas 30\% luas desa yang dapat dilihat pada tabel di atas ( ${ }^{1}$ Nurkholis, dkk, 2016). Data lain yang digunakan adalah data jumlah penduduk yang berada di dalam bentuklahan lereng kaki yaitu sebesar 2.438 jiwa di Desa Pakembinangun, 2.610 jiwa di Desa Umbulmartani, 6.836 jiwa di Desa Sukoharjo, dan 613 jiwa di Desa Sardonoharjo.

Tabel 4.1 DDW untuk Permukiman DAS Sembung

\begin{tabular}{|c|c|c|c|c|c|c|}
\hline BL & Desa & L.Lp & Pd & $\begin{array}{l}\text { Koef.kebutuhan } \\
\text { lahan per-orang }\end{array}$ & DDP @ Desa & DDP@BL \\
\hline \multirow{4}{*}{$\begin{array}{l}\text { Lereng } \\
\text { Kaki }\end{array}$} & Pakembinangun & 528898 & 2438 & \multirow{9}{*}{26,67} & 8,1 & \multirow{4}{*}{6,1} \\
\hline & Umbulmartani & 611216 & 2610 & & 8,8 & \\
\hline & Sukoharjo & 654944 & 6836 & & 3,6 & \\
\hline & Sardohoharjo & 63707 & 613 & & 3,9 & \\
\hline \multirow{5}{*}{$\begin{array}{c}\text { Dataran } \\
\text { Kaki }\end{array}$} & Wedomartani & 405300 & 2826 & & 5,4 & \multirow{5}{*}{3,9} \\
\hline & Sukoharjo & 654944 & 6836 & & 3,6 & \\
\hline & Sinduharjo & 131553 & 1391 & & 3,5 & \\
\hline & Condongcatur & 941 & 18 & & 2,0 & \\
\hline & Maguwoharjo & 76914 & 573 & & 5,0 & \\
\hline
\end{tabular}

Hasil perhitungan DDW untuk permukiman pada bentuklahan dataran kaki adalah sebesar 3,9 yang menunjukkan bahwa bentuklahan ini dapat mendukung permukiman dengan tinggi. Bentuklahan dataran kaki ini meliputi 5 administrasi desa yang memiliki jumlah penduduk 
dan luas lahan layak untuk permukiman yang berbeda-beda. Hasil perhitungan DDP antara lereng kaki lebih besar daripada DDP pada dataran kaki gunungapi, hal ini disebabkan karena faktor L.Lp dan Pd yang lebih besar pada bentuklahan lereng kaki.

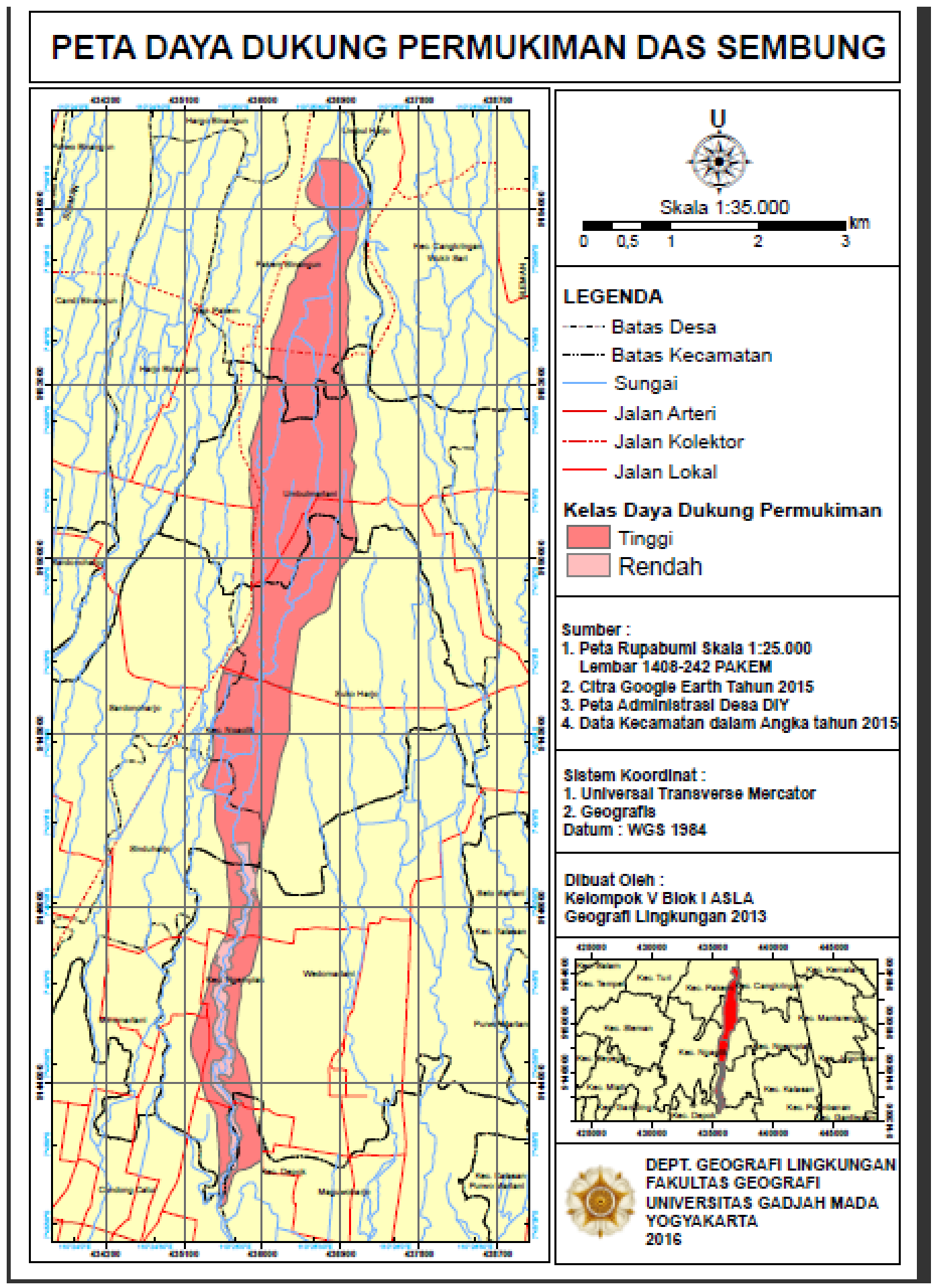

Gambar 4.1. Peta Daya Dukung Permukiman DAS Sembung 
Selain faktor L.Lp dan Pd, lebih besarnya nilai DDP pada lereng kaki dibandingkan dataran kaki dapat disebabkan oleh banyak faktor, diantaranya yaitu, udara di lereng kaki yang lebih sejuk dan harga lahan yang relatif lebih murah. Faktor-faktor tersebut merupakan beberapa faktor pendorong yang menyebabkan DDP pada lereng kaki lebih besar. Selain itu, juga disebabkan karena cakupan bentuklahan dataran kaki pada DAS Sembung lebih kecil dibandingkan luasan bentuklahan lereng kaki.

\section{B. Daya Dukung Wilayah terhadap Pertanian}

Besarnya kemampuan atau daya dukung wilayah sangat menentukan keberlangsungan kebutuhan hidup. Manusia dalam memenuhi kebutuhan hidupnya, membutuhkan pangan yang diperoleh dari hasil pemanfaatan lahan. Pemanfaatan lahan ini dapat berupa pertanian dan nonpertanian. Pemanfaatan lahan tergantung dari keadaan geomorfologis dan populasi wilayah. Area DAS Sembung terdapat 2 bentuklahan yang potensial mendukung kegiatan pertanian wilayah yaitu lereng kaki dan dataran kaki volkanik.

Analisis daya dukung wilayah untuk lahan pertanian di DAS Sembung pada satuan bentuklahan lereng kaki berdasarkan Tabel 4.2 diperoleh nilai daya dukung sebesar 1,3, sedangkan pada dataran kaki yaitu 0,06. Daya dukung wilayah di dataran kaki untuk pertanian terklasifikasikan ke dalam kelas tinggi, sedangkan di dataran kaki termasuk ke dalam kelas rendah (Gambar 4.2). Kelas yang demikian tinggi di satuan bentuklahan lereng menunjukan bahwa lahan pertanian di wilayah tersebut cukup mampu mendukung beban yang ada. Kondisi yang demikian juga menunjukan adanya sinergitas antara kondisi fisik wilayah dan kegiatan manusianya. Area lereng kaki memiliki kondisi fisik wilayah yang sangat cocok untuk pertanian, Selaras dengan kegiatan pertanian yang cukup tinggi di area tersebut, dilihat dari niai produktivitasnya yang tinggi, hingga menghasilkan nilai daya dukung wilayah yang tinggi juga untuk pertanian.

Daya dukung yang rendah di satuan dataran kaki wilayah DAS Sembung menunjukan bahwa lahan pertanian di wilayah tersebut belum mampu mendukung beban yang ada. Beban yang dimaksud didalamnya adalah tanggungan terhadap jumlah populasi penduduk dan konsumsi penduduk di sekitar DAS. Kondisi daya dukung pertanian yang rendah selaras dengan kondisi daya dukung pemukimannya yang tinggi. Wangge dkk (2016) menyatakan bahwa tekanan penduduk terhadap lahan pertanian di kawasan dataran kaki lebih tinggi dibandingkan lereng kaki. Hal ini menjadi salah satu bukti bahwa daya dukung pertanian di dataran kaki menjadi rendah karena banyak permukiman telah dan akan dibangun. 


\section{PETA DAYA DUKUNG PERTANIAN DAS SEMBUNG}

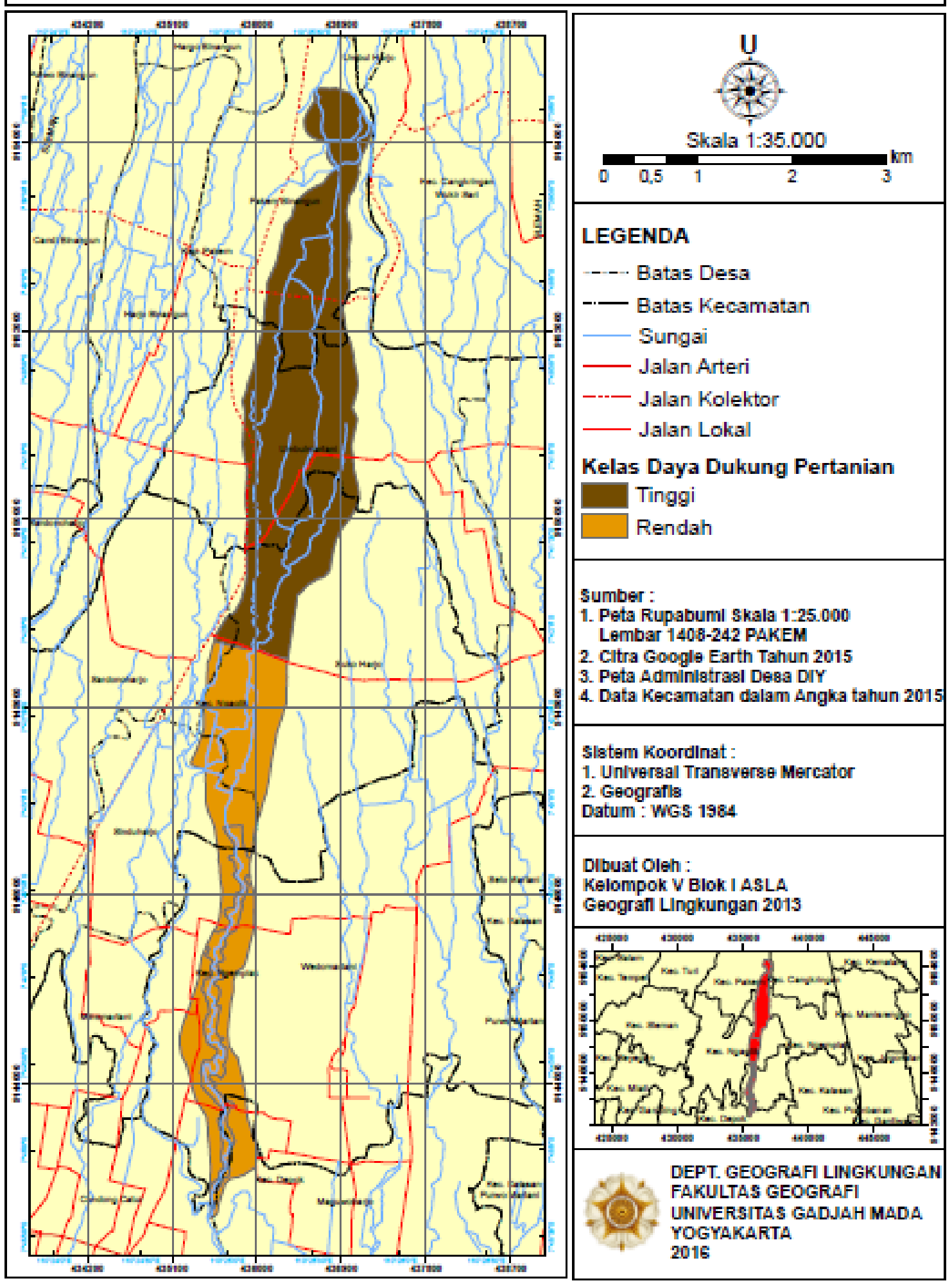

Gambar 4.2. Peta Daya Dukung terhadap Lahan Pertanian di DAS Sembung 
Tabel 4.2. Daya Dukung Wilayah Terhadap Pertanian DAS Sembung

\begin{tabular}{|c|c|c|c|c|c|}
\hline 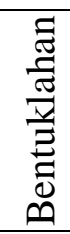 & $\begin{array}{l}\mathscr{̋} \\
\stackrel{\tilde{\nu}}{0}\end{array}$ & $\begin{array}{l}\text { P (Jumlah } \\
\text { Penduduk) }\end{array}$ & $\begin{array}{c}\text { LP } \\
\text { (Luas } \\
\text { Panen) }\end{array}$ & $\begin{array}{c}\text { Pr (Produksi } \\
\text { lahan rata- } \\
\text { rata) }\end{array}$ & DDW \\
\hline \multirow{4}{*}{ 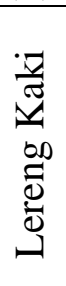 } & Pakembinangun & 2438 & 155,98 & 9389,61 & \multirow{4}{*}{1,30} \\
\hline & Umbulmartani & 2610 & 144,89 & 19,42 & \\
\hline & Sardonoharjo & 613 & 16,71 & 101,92 & \\
\hline & Sukoharjo & 6923 & 279 & 1701,87 & \\
\hline \multirow{5}{*}{ 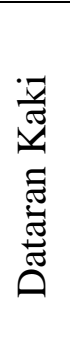 } & Sukoharjo & 2826 & 107,399 & 6,74 & \multirow{5}{*}{0,06} \\
\hline & Wedomartani & 6836 & 104,435 & 626,61 & \\
\hline & Sinduharjo & 1391 & 56,039 & 341,84 & \\
\hline & Condongcatur & 18 & 0,079 & 0,03 & \\
\hline & Maguwoharjo & 573 & 14,947 & 1,37 & \\
\hline
\end{tabular}

\section{Daya Dukung Wilayah terhadap Kawasan Lindung}

Hasil perhitungan indeks kawasan lindung lingkungan adalah sebesar 2,76 di bagian lereng kaki, sebesar 3,02 di bagian dataran kaki, dan sebesar 2,38 di baguan teras sungai (Tabel 4.3). Hasil perhitungan daya dukung lindung ialah sebesar 0,36 di bagian lereng kaki, sebesar 0,33 di bagian dataran kaki dan sebesar 042 di bagian teras sungai. Hasil tersebut menunjukkan bahwa di DAS Sembung daya dukung lingkungannya rendah atau dapat dikatakan rusak baik di daerah lereng kaki maupun di daerah dataran kaki karena lahan di sekitar DAS Sembung bukan lagi lahan yang alami melainkan sudah banyak mengalami pengolahan (Gambar 4.3). Hal tersebut dilakukan warga desa di sekitar DAS Sembung untuk memenuhi kebutuhan hidup penduduknya sebagai tempat tinggal serta mata pencahariaannya, sedangkan pada wilayah teras sungai daya dukung lindungnya masih tergolong sedang karena pengolahan yang dilakukan tidak sebesar pada lereng kaki dan dataran kaki.

Pengolahan yang dilakukan pada wilayah teras sungai adalah sebagai perkebunan sehingga pengolahannya tidak menimbulkan kerusakan yang besar. Daya dukung lindung di bagian lereng kaki dan dataran kaki memiliki perbedaan yang tidak signifikan karena apabila dilihat dari kenampakan fisik wilayahnya pun tidak jauh berbeda sementara di bagian teras sungai memiliki perbedaan yang cukup terlihat. 


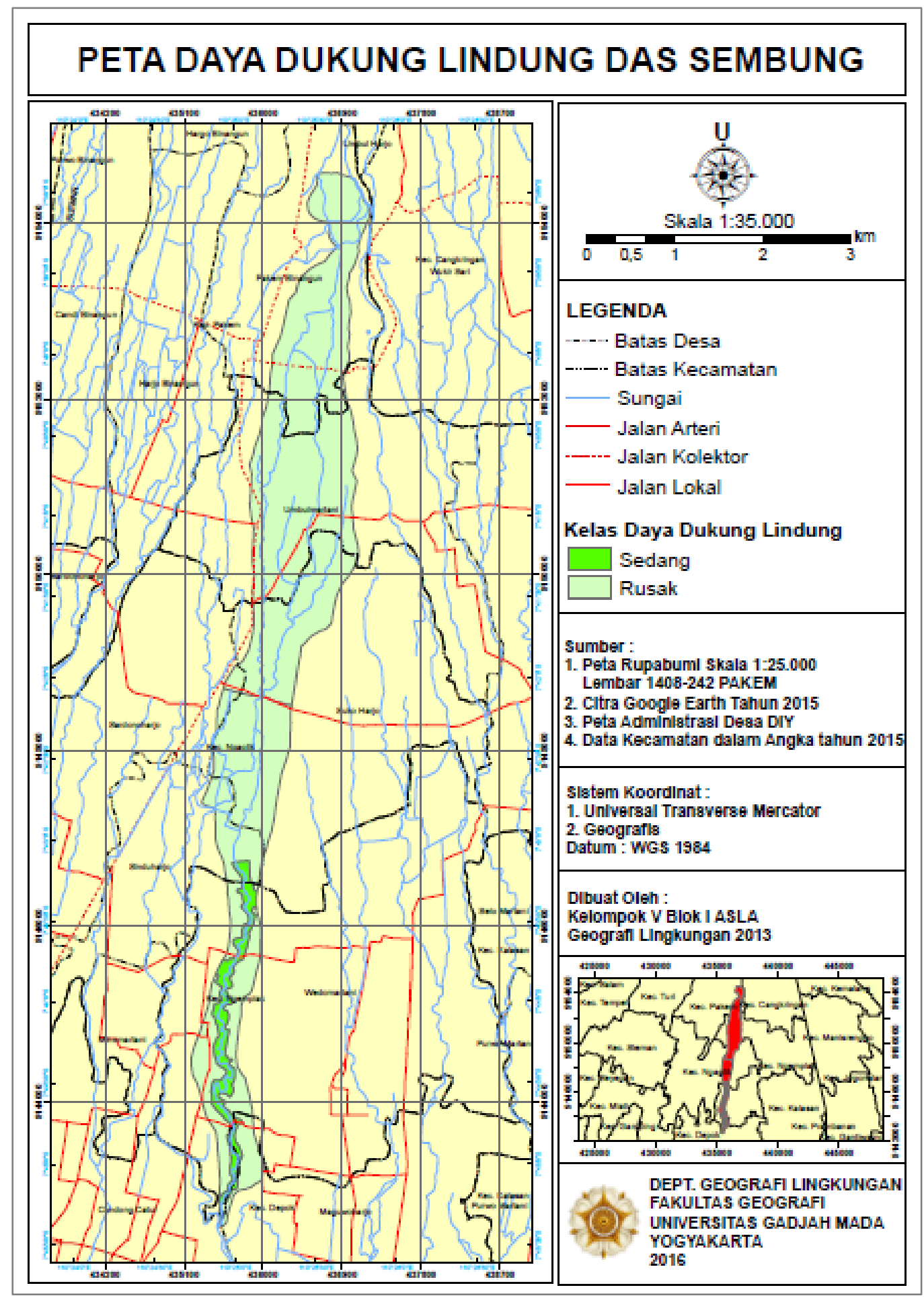

Gambar 4.3. Peta Daya Dukung terhadap Kawasan Lindung di DAS Sembung

Daya dukung lindung yang lebih tinggi pada daerah lereng kaki terjadi karena luas wilayah pada daerah lereng kaki yang lebih besar daripada di daerah dataran kaki, sedangkan daya dukung lindung pada teras sungai merupakan yang paling besar karena pengolahannya hanya 
sebagai kebun. Selain itu, daerah lereng kaki lebih banyak ditemukan penggunaan lahan sawah dan di bagian dataran kaki lebih banyak ditemukan penggunaan lahan permukiman. Hal tersebut menyebabkan perbedaan nilai daya dukung lahan di lereng kaki, di dataran kaki dan di teras sungai.

Tabel 4.3. Perhitungan IKLL (Indeks Kawasan Lindung Lingkungan) dan

DDL (Daya Dukung Lingkungan)

\begin{tabular}{|l|c|c|c|c|c|c|c|c|c|c|}
\hline $\begin{array}{c}\text { koef } \\
\text { kebun }\end{array}$ & $\begin{array}{c}\text { lahan } \\
\text { kebun }\end{array}$ & $\begin{array}{c}\text { koef } \\
\text { permukiman }\end{array}$ & $\begin{array}{c}\text { lahan } \\
\text { permukiman }\end{array}$ & $\begin{array}{c}\text { koef } \\
\text { sawah }\end{array}$ & $\begin{array}{c}\text { lahan } \\
\text { sawah }\end{array}$ & $\begin{array}{c}\text { koef } \\
\text { tegalan }\end{array}$ & $\begin{array}{c}\text { lahan } \\
\text { tegalan }\end{array}$ & $\begin{array}{c}\text { luas } \\
\text { wilayah }\end{array}$ & IKLL & DDL \\
\hline \multicolumn{7}{|c|}{ Lereng Kaki } \\
\hline 0,42 & 3,20 & 0,18 & 172,38 & 0,46 & 321,97 & 0,21 & 3,40 & 500,95 & 2,76 & 0,36 \\
\hline \multicolumn{8}{|c|}{ Dataran Kaki } \\
\hline 0,42 & 9,69 & 0,18 & 126,39 & 0,46 & 141,31 & 0,21 & 0,00 & 277,38 & 3,02 & 0,33 \\
\hline \multicolumn{7}{|c|}{ teras sungai } \\
\hline 0,42 & 35,54 & 0,18 & 0,00 & 0,46 & 0,00 & 0,21 & 0,00 & 35,54 & 2,381 & 0,42 \\
\hline
\end{tabular}

\section{KESIMPULAN}

Hasil perhitungan daya dukung terhadap permukiman menunjukkan bahwa pada lereng kaki dan dataran kaki memiliki daya dukung yang tinggi sedangkan pada bentuklahan teras sungai memiliki daya dukung permukiman yang rendah. Hal ini dipengaruhi oleh faktor luas lahan layak permukiman dan jumlah penduduk pada masing-masing bentuklahan. Hasil perhitungan daya dukung pertanian menunjukkan bahwa lereng kaki memiliki daya dukung yang tergolong tinggi sedangkan pada dataran kaki dan teras sungai memiliki daya dukung yang rendah, hal ini disebabkan karena tekstur tanah di lereng kaki adalah geluh berpasir yang cocok untuk pertanian sedangkan tektur tanah pada dataran kaki dan teras sungai dominan pasir. Hasil perhitungan daya dukung lindung menunjukkan bahwa pada bentuklahan lereng kaki dan dataran kaki memiliki daya dukung yang tergolong rusak sedangkan pada teras sungai tergolong sedang. Hal ini sangat dipengaruhi oleh kondisi alami yang ada pada lereng kaki dan dataran kaki telah banyak berubah akibat aktivitas manusia. 


\section{DAFTAR PUSTAKA}

Barrow, C.J. 1991. Degradation of Tropical Rain Forest, Tropical/Sub Tropical Seasonally Organisme ang Tropical/Sub Tropical Upland Forests, Woodlands and Saruglands. Land Degradation Development and Breakdown of Terrestrial Environments. Cambridge-UK.

Nurkholis, A., Widyaningsih, Y., Rahma, A. D., Suci, A., Abdillah, A., Wangge, G. A., Widiastuti, A. S., Maretya, D. A. 2016. Analisis Kemampuan Dan Kesesuaian Lahan di DAS Sembung, Kabupaten Sleman, DIY. http://doi.org/10.17605/OSF.IO/M9DKN

Soemarwoto, O., 1985. A Qualitative of Population Pressure and It's Potential Use in Development Planning. Majalah Demografi Indonesia, 12 (24)

Soerjani, et al. 1987. Lingkungan: Sumber Daya Alam dan Kependudukan dalam Pembangunan. Jakarta: Penerbit Universitas Pendidikan Indonesia.

Wangge, G. A., Widiastuti, A. S., Maretya, D. A., Suci, A., Nurkholis, A., Widyaningsih, Y., Rahma, A. D., Abdillah, A. 2016. Tekanan Penduduk Terhadap Lahan Pertanian di DAS Sembung, Kabupaten Sleman, DIY. http://doi.org/10.17605/OSF.IO/EDAHR 